\title{
Iron and Folate Metabolism in Tuberculosis
}

\author{
P. D. ROBERTS, * M.D., D.PATh. ; A. V. HOFFBRAND, † M.A., B.M., M.R.C.P., D.C.P. \\ D. L. MOLLIN, $\ddagger$ M.B., B.SC., M.R.C.P., M.C.PATH.
}

Brit. med. F., 1966, 2, 198-202

Hypochromic anaemia associated with the accumulation of excessive numbers of iron granules in the perinuclear zone of erythroblasts ("sideroblastic anaemia") has been described in patiènts being treated with isoniazid (Redleaf, 1962 ; Kohn et al., 1962 ; McCurdy, 1963 ; MacGibbon and Mollin, 1965). The condition is apparently very rare in patients receiving isoniazid alone, and it may be that this drug affects only the haemopoietic tissue of certain susceptible individuals. However, sideroblastic anaemia does not appear to be infrequent in patients given isoniazid in conjunction with other antituberculous drugs such as cycloserine or pyrazinamide (Verwilghen et al., 1963, 1965). The combination of these drugs is also more effective in producing sideroblastic anaemia in experimental animals than the administration of isoniazid alone (Harriss et al., 1965). It therefore seems possible that the incidence and severity of sideroblastic anaemia in patients receiving antituberculous treatment is partly related to the dose and the type of drug given. If this is minor degrees of sideroblastic change might be more common in patients receiving antituberculous therapy than has previously been suspected. To investigate this point haematological studies were carried out on a group of tuberculous patients receiving chemotherapy.

Early in this survey it became apparent that many of the patients showed haematological evidence of folate deficiency. The investigation was therefore extended to determine the incidence and cause of folate deficiency in these tuberculous patients. This paper reports the results of both studies.

\section{Subjects Studied}

Observations were made on 68 randomly selected tuberculous patiěnts (44 males, 24 females) and 50 control subjects.

The patients' ages ranged from 17 to 72 (mean 42.6 years). Thirty were studied as outpatients and the remainder were in hospital. Sixty-two had pulmonary tuberculosis, two tuberculous adenitis, two renal tuberculosis, one pelvic tuberculosis, and one tuberculous bursitis. The severity of the disease in the patients with pulmonary tuberculosis varied from early single lesions, in some detected by routine radiography, to widespread cavitation in chronically ill patients. In Table I

TABLE I.-Classification of the 62 Patients with Pulmonary Tuberculosis

\begin{tabular}{c|c|c}
$X$-ray Classification & No. of Cases & Sputum-Positive \\
\hline II & 22 & 1 \\
III & 28 & 6 \\
\hline
\end{tabular}

the cases are grouped according to the radiological extent of the dišease (Foster-Carter et al., 1952). Class I had one zone in one lung involved; class II two to three zones involved,

\footnotetext{
* Consultant Haematologist, Department of Haematology, West Middlesex Hospital, Isleworth, Middlesex.

t Member of the Medical Research Council Group for Research into Megaloblastic and Sideroblastic Anaemias; Honorary Senior Registrar, Department of Haematology, Postgraduate Medical School of London.

‡ Difector of the Medical Research Council Group for Research into Megaloblastic and Sideroblastic Anaemias; Senior Lecturer, Department of Haematology, Postgraduate Medical School of London.
}

unilateral or bilateral; and class III had four or more zones involved. The number of patients who were sputum-positive for tubercle bacilli at the time of examination is also indicated.

Forty-six patients were taking antituberculous drugs, four had temporarily stopped treatment, and 18 were investigated before starting chemotherapy. The chemotherapy given was as follows :

Group A.-Treated by P.A.S. (para-aminosalicylic acid), isoniazid, and initially streptomycin; less than 6 months in 13 cases, 6-12 months in 13, and more than 12 months in 17 .

Group B.-Treated by other antituberculous drugs (all for less than six months): ethionamide, P.A.S., and isoniazid in one case ; pyrazinamide and isoniazid in one case; and cycloserine and isoniazid in one case.

Group C.-Previously treated by chemotherapy but not at the time of investigation-four cases.

Group D.-Untreated-18 cases.

The control group was made up of 50 adult hospital outpatients ( 25 males, 25 females) requiring venepuncture for other investigations. They were randomly selected, but antenatal patients and known anaemic patients were excluded. Their ages ranged from 17 to 83 years, with a mean age of 49 .

\section{Methods}

Haematological studies were carried out with standard methods (Dacie and Lewis, 1963). Bone-marrow films were stained by May-Grünwald-Giemsa and by Perls's method for iron; the changes present were classified as: (1) minimal, occasional giant metamyelocytes and rare intermediate megaloblasts ; (2) mild, many giant metamyelocytes and occasional intermediate megaloblasts ; (3) obvious, many giant metamyelocytes and many easily recognized intermediate megaloblasts.

Polymorph nuclear lobe counts were performed on stained peripheral blood films. One hundred cells were examined in each film and the mean nuclear lobe count (Herbert, 1959) and the number of cells showing six or more nuclear lobes were recorded by two independent observers.

Serum folate levels were measured in duplicate on two serum specimens by microbiological assay with Lactobacillus case $i$ A.T.C.C. 1469, with the method of Waters and Mollin (1961), the normal level ranging from 5.9 to $21 \mathrm{~m} \mu \mathrm{g}$./ml. Patients with megaloblastic anaemia due to folate deficiency usually have levels below $3.0 \mathrm{~m} \mu \mathrm{g} . / \mathrm{ml}$.

Red-cell folate levels were measured by estimating the $L$. casei activities of haemolysates of sequestrenized whole-blood samples (Hoffbrand et al., 1966). The normal range is from 160 to $640 \mathrm{~m} \mu \mathrm{g} . / \mathrm{ml}$. of packed red cells.

Serum vitamin $B_{12}$ levels were assayed in duplicate on two serum specimens by the method of Anderson (1964) with the use of the " $\mathrm{z}$ " strain of Euglena gracilis. With this method the normal range is from 160 to $925 \mu \mu \mathrm{g} . / \mathrm{ml}$.

Formiminoglutamic acid (Figlu) was measured in an eighthour urine specimen after an oral dose of $15 \mathrm{~g}$. of L-histidine monohydrochloride, by the spectrophotometric method of Chanarin and Bennett (1962). Folate-deficient subjects excrete more than $17 \mathrm{mg}$. of Figlu in the eight-hour period. This 
method measures both Figlu and urocanic acid ; in the present study the value for Figlu alone is given.

Serum iron levels and total serum iron-binding capacities were determined by the method of Caraway (1963). The normal serum iron concentration ranges from 65 to $150 \mu \mathrm{g}$./ $100 \mathrm{ml}$, and the normal total iron-binding capacity ranges from 250 to $400 \mu \mathrm{g}$. $/ 100 \mathrm{ml}$.

\section{Procedure}

Blood counts, bone-marrow aspirations, serum folate and $B_{12}$ assays, and serum iron estimations were carried out on all the tuberculous patients. In 19 unselected patients Figlu excretion, and in nine unselected patients red-cell folate levels, were also measured. On the control subjects only the haematological studies on the peripheral blood and serum folate and $\mathrm{B}_{12}$ assays were performed.

\section{Results}

\section{Incidence of Anaemia}

Of the 68 tuberculous patients $12(18 \%)$ were anaemic (haemoglobin level less than $13.5 \mathrm{~g} . / 100 \mathrm{ml}$. in males and less than $11.5 \mathrm{~g} . / 100 \mathrm{ml}$. in females) (Table II). In seven patients (Cases 1-7) the anaemia was due to deficiency of iron or folate, or of both. In the remaining five anaemic patients (Cases 8-12) the anaemia was normochromic normocytic, and the bonemarrow changes were not severe enough for the anaemia to be regarded as entirely due to folate deficiency, though the serum folate levels were low. Three non-anaemic patients had a raised mean corpuscular volume, with obvious macrocytosis in the peripheral blood film. Each showed obvious megaloblastic changes and had a low serum folate level (Table II).

Eight of the 50 control subjects were mildly anaemic (haemoglobin range 10.4-13.4 g./100 ml.). The peripheral blood films of the three most anaemic showed hypochromasia; none of the controls showed macrocytosis.

\section{Incidence of Megaloblastic Change and Folate Deficiency}

Fig. 1 compares the serum folate levels of the tuberculous patients with those of the control subjects. Twenty-one (42\%) of the controls had subnormal levels, but all were above $3.0 \mu \mathrm{g} . / \mathrm{ml}$. In contrast, $60(88 \%)$ of the tuberculous patients had serum folate levels below $6.0 \mu \mathrm{g} . / \mathrm{ml}$., and in $24(35 \%)$ the levels were below $3.0 \mu \mathrm{g} . / \mathrm{ml}$.
The serum $B_{12}$ levels of the tuberculous patients and controls were all normal except for one non-anaemic patient who had a serum $B_{12}$ level of $1,140 \mu \mu \mathrm{g}$./ml., just above the upper limit of the normal range.

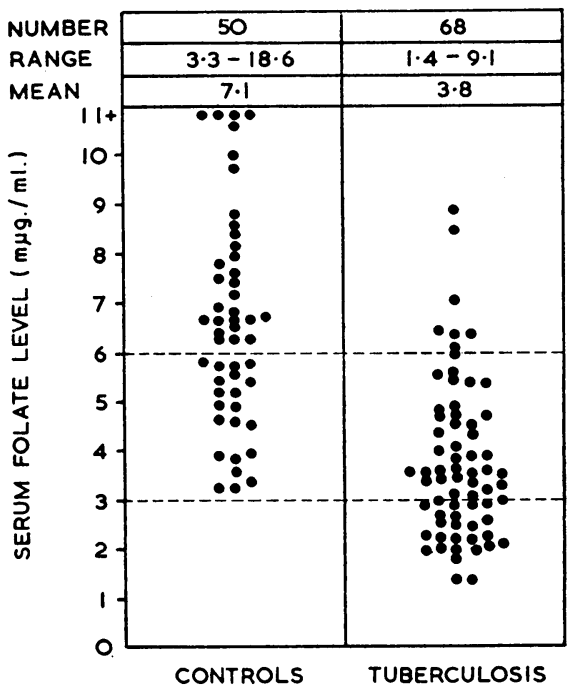

FIG. 1.-Range, mean, and distribution of the serum folate levels of the tuberculous patients and control subjects.

Provided $\mathrm{B}_{12}$ deficiency has been excluded, the presence of hypersegmented polymorphs in the peripheral blood films is usually an indication of folate deficiency. As shown in Table III, the tuberculous patients had significantly increased lobe counts compared with the control subjects. In Table IV the counts of one observer are compared with the serum folate levels of the corresponding patients. Although all 23 patients with hypersegmented cells had subnormal serum folate levels and $57 \%$ had levels less than $3.0 \mu \mathrm{g} . / \mathrm{ml} ., 82 \%$ of the 45 patients without hypersegmented cells also had subnormal serum folate

TABLE III.-Polymorph Nuclear Lobe Counts of the 50 Control Subjects and of the 68 Tuberculous Patients, Performed by Two Independent Observers

\begin{tabular}{l|c|c|c|c} 
& \multicolumn{2}{|c|}{ Observer A } & \multicolumn{2}{c}{ Observer B } \\
\hline & Controls & T.B. & Controls & T.B. \\
\hline $\begin{array}{l}\text { Range of mean lobe counts } \\
\text { Mean of mean lobe counts }\end{array}$ & $2 \cdot 64-3 \cdot 36$ & $2 \cdot 50-3 \cdot 85$ & $2 \cdot 58-3 \cdot 37$ & $2 \cdot 43-4 \cdot 18$ \\
$\begin{array}{l}\text { No. with mean lobe count } \\
\text { >3.30 }\end{array}$ & $4(8 \%)$ & $22(32 \%)$ & $2(4 \%)$ & $30(44 \%)$ \\
$\begin{array}{l}\text { No. with hypersegmented } \\
\text { cells } . .\end{array}$ & $4(8 \%)$ & $23(34 \%)$ & $3(6 \%)$ & $20(29 \%)$ \\
\hline
\end{tabular}

TABLE II.-Haematological and Biochemical Findings in the 12 Anaemic Patients (Cases 1-12) and the Three Non-anaemic Patients with Macrocytosis (Cases 13-15)

\begin{tabular}{|c|c|c|c|c|c|c|c|c|c|c|c|c|c|}
\hline \multirow{2}{*}{$\begin{array}{l}\text { Case } \\
\text { No. }\end{array}$} & \multirow{2}{*}{ Sex } & \multirow{2}{*}{$\begin{array}{c}\mathrm{Hb} \\
(\mathrm{g} . / \\
100 \mathrm{ml} .)\end{array}$} & \multirow{2}{*}{$\underset{(\%)}{\text { M.C.H.C. }}$} & \multirow{2}{*}{$\begin{array}{l}\text { M.C.V. } \\
\text { (cubic } \mu \text { ) }\end{array}$} & \multirow{2}{*}{$\begin{array}{l}\text { Peripheral } \\
\text { Film }\end{array}$} & \multicolumn{2}{|c|}{$\begin{array}{c}\text { Hypersegmented } \\
\text { Polymorphs }\end{array}$} & \multirow{2}{*}{$\begin{array}{l}\text { Bone- } \\
\text { marrow } \\
\text { Changes }\end{array}$} & \multirow{2}{*}{$\begin{array}{l}\text { Bone- } \\
\text { marrow } \\
\text { Iron }\end{array}$} & \multirow{2}{*}{$\begin{array}{c}\text { Serum } \\
\text { Iron } \\
\text { Level } \\
(\mu \mathrm{g} .1 \\
100 \mathrm{ml} .)\end{array}$} & \multirow{2}{*}{$\begin{array}{l}\text { T.I.B.C. } \\
(\mu \mathrm{g} . / \\
100 \mathrm{ml} .)\end{array}$} & \multirow{2}{*}{$\begin{array}{c}\text { Serum } \\
\text { Folate } \\
\text { Level } \\
\text { (m } \mu \mathrm{gg} . / \\
\text { ml.) }\end{array}$} & \multirow{2}{*}{ Diagnosis } \\
\hline & & & & & & $\begin{array}{c}\text { Observer } \\
\text { A }\end{array}$ & $\begin{array}{c}\text { Observer } \\
\text { B }\end{array}$ & & & & & & \\
\hline 1 & $\mathbf{M}$ & $12 \cdot 1$ & 29 & 96 & Hypochromic & - & - & Minimal & Absent & 50 & 250 & $2 \cdot 3$ & \\
\hline $\begin{array}{l}2 \\
3\end{array}$ & $\stackrel{M}{M}$ & $\begin{array}{l}12.5 \\
12.5\end{array}$ & $\begin{array}{l}29 \\
29\end{array}$ & $\begin{array}{l}84 \\
86\end{array}$ & "” & $\overline{+}$ & $\begin{array}{l}+ \\
+\end{array}$ & Mild & ", & $\begin{array}{l}57 \\
28\end{array}$ & $\begin{array}{l}255 \\
261\end{array}$ & $\begin{array}{l}6 \cdot 5 \\
2 \cdot 2\end{array}$ & $\begin{array}{l}\text { Mainly } \\
\text { iron-deficiency }\end{array}$ \\
\hline 4 & $\mathbf{M}$ & $10 \cdot 4$ & 28 & 84 & ” & + & + & $\begin{array}{c}\text { megainimal } \\
\text { Minimal }\end{array}$ & ” & 26 & 150 & $4 \cdot 6$ & gngemis \\
\hline $\begin{array}{l}5 \\
6\end{array}$ & $\underset{\mathbf{M}}{\mathbf{F}}$ & $\begin{array}{l}10 \cdot 0 \\
12 \cdot 1\end{array}$ & $\begin{array}{l}27 \\
31\end{array}$ & $\begin{array}{r}73 \\
100\end{array}$ & Macrocytic & $\overline{+}$ & $\overline{+}$ & $\begin{array}{l}\text { Normoblastic } \\
\text { Obvious }\end{array}$ & Present & $\begin{array}{l}14 \\
47\end{array}$ & $\begin{array}{l}269 \\
195\end{array}$ & $\begin{array}{l}3.5 \\
2.1\end{array}$ & Megaloblastic \\
\hline 7 & $\mathbf{F}$ & $10 \cdot 8$ & 32 & 78 & Dimorphic & - & - & $\begin{array}{c}\text { megaloblastic } \\
\text { " },\end{array}$ & Absent & 51 & 404 & $6 \cdot 0$ & $\begin{array}{l}\text { anaemia } \\
\text { Mixed iron- and } \\
\text { folate-deficiency } \\
\text { anaemia }\end{array}$ \\
\hline 8 & $\mathbf{M}$ & $11 \cdot 7$ & 31 & 88 & $\begin{array}{c}\text { Normochromic } \\
\text { normocytic }\end{array}$ & + & - & $\begin{array}{l}\text { Mild } \\
\text { megaloblastic }\end{array}$ & Present & 27 & 270 & $2 \cdot 3$ & \\
\hline $\begin{array}{r}9 \\
10 \\
11 \\
12 \\
13\end{array}$ & $\begin{array}{l}M \\
M \\
M \\
M \\
M\end{array}$ & $\begin{array}{l}11 \cdot 2 \\
12.5 \\
12.1 \\
13.0 \\
14.6\end{array}$ & $\begin{array}{l}31 \\
31 \\
30 \\
32 \\
30\end{array}$ & $\begin{array}{r}92 \\
96 \\
78 \\
81 \\
102\end{array}$ & $\begin{array}{c}\text { ", } \\
\text { "” } \\
\text { Macrocytic }\end{array}$ & $\begin{array}{l}+ \\
\pm \\
+ \\
+\end{array}$ & $\begin{array}{l}+ \\
\pm \\
+ \\
+\end{array}$ & $\begin{array}{c}\text { ", ", } \\
\text { ", } \\
\text { Normoblastic } \\
\text { Obvious } \\
\text { megaloblastic }\end{array}$ & $\begin{array}{c}\text { Reduced } \\
\text { Present } \\
\text { ” } \\
\text { " }\end{array}$ & $\begin{array}{r}23 \\
91 \\
23 \\
33 \\
110\end{array}$ & $\begin{array}{l}225 \\
315 \\
282 \\
240 \\
306\end{array}$ & $\begin{array}{l}4 \cdot 2 \\
5 \cdot 0 \\
2 \cdot 5 \\
3 \cdot 6 \\
1 \cdot 2\end{array}$ & $\begin{array}{l}\begin{array}{c}\text { Normochromic } \\
\text { normocytic } \\
\text { angemia }\end{array} \\
\text { Macrocytic, }\end{array}$ \\
\hline $\begin{array}{l}14 \\
15\end{array}$ & $\underset{F}{F}$ & $\begin{array}{l}12 \cdot 5 \\
12 \cdot 1\end{array}$ & $\begin{array}{l}33 \\
33\end{array}$ & $\begin{array}{l}107 \\
106\end{array}$ & ", & \pm & \pm & ", ", & ", & $\begin{array}{r}108 \\
44\end{array}$ & $\begin{array}{l}240 \\
195\end{array}$ & $\begin{array}{l}1 \cdot 4 \\
2 \cdot 3\end{array}$ & $\begin{array}{l}\text { without } \\
\text { anaemia }\end{array}$ \\
\hline
\end{tabular}


levels and $24 \%$ had levels less than $3.0 \mu \mathrm{g} . / \mathrm{ml}$. Subnormal serum folate levels were therefore far more common than the presence of hypersegmented cells.

TABLE IV.-Comparison of the Serum Folate Levels with the Presence or Absence of Hypersegmented Polymorphs (Assessed by Observer A) in the Siained Peripheral Blood Films of the Tuberculous Subjects

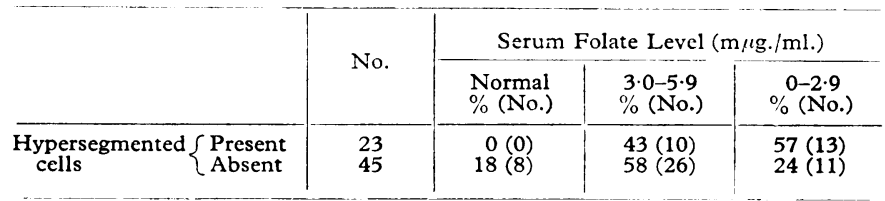

The bone-marrow films were examined without prior knowledge of the serum folate levels. The incidence of megaloblastic changes in the 68 tuberculous patients is illustrated in Fig. 2. In $15(22 \%)$ the marrows were normoblastic, $12(17 \%)$ showed minimal changes, 21 (31\%) mild changes, and $20(30 \%)$ obvious changes. Patients with mild and obvious megaloblastic changes had lower mean serum folate levels than those with minimal changes or normal marrows (Fig. 2). However, at any given serum folate level there was wide variation in marrow appearance.

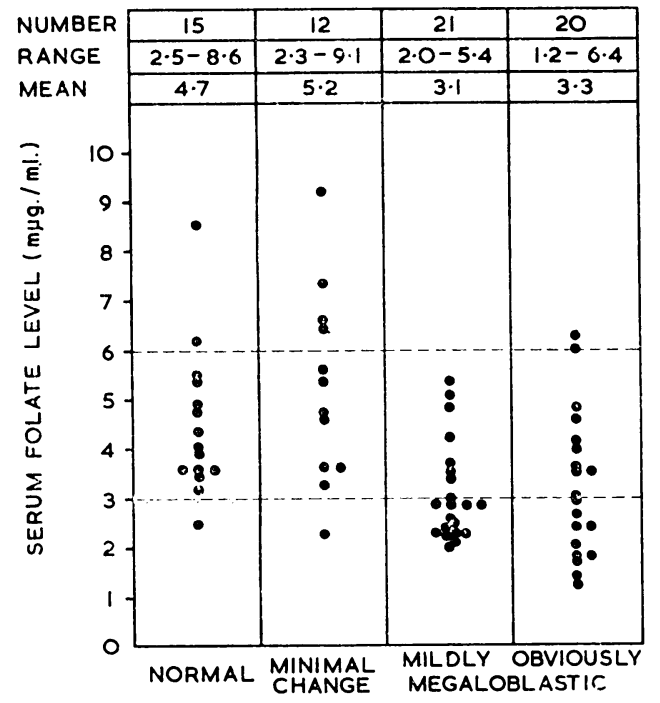

FIG. 2.-Comparison of the serum folate levels of the tuberculous patients with their bone-marrow appearances.

Three of the nine randomly selected patients tested had subnormal red-cell folate levels $(78,148$, and $155 \mu \mu \mathrm{g} . / \mathrm{ml}$.). These three patients all had obvious megaloblastic changes, whereas the marrow was normoblastic (2) or showed minimal (2) or mild (2) megaloblastic changes in the six patients with normal red-cell folate levels. Nine of 19 patients tested excreted abnormal amounts of Figlu (range from 25 to $120 \mathrm{mg}$. in eight hours). Positive Figlu tests were restricted to patients showing megaloblastic changes, two showing obvious, five mild, and two minimal changes. Figlu tests were negative in five patients with normoblastic marrows, but also in two with minimal and three with mild changes.

\section{Iron Studies}

The distribution of stainable iron in the bone-marrow of the tuberculous patients is detailed in Table V. Five of the 68 aspirates contained no marrow fragments and were inadequate for assessment of the iron content and distribution. The remaining 63 specimens could be classified into four groups: (1) normal, (2) iron-deficient, (3) changes of infection, and (4) iron excess.

(1) In $15(24 \%)$ the distribution of iron was normal, normal amounts of free iron being present in the fragments, and iron granules occurring in 20 to $50 \%$ of the developing erythroblasts. These granules were fine, were randomly distributed in the cytoplasm, and not more than five granules were present in a single cell.

(2) Nineteen $(30 \%)$ of the marrows were iron-deficient, iron being completely or almost completely absent from both fragments and erythroblasts.

(3) In a further 10 specimens (16\%) there was normal, increased, or slightly reduced iron in the fragments, but iron was absent from the erythroblasts; these changes were interpreted as being caused by chronic inflammatory disease.

(4) The remaining 19 marrows (30\%) also showed normal, reduced, or increased iron in the fragments, but were remarkable in that the erythroblasts contained an excess of iron granules. These granules were larger and more easily seen than normal; many of the cells contained more than five granules, which were often grouped around the nucleus, forming incomplete rings and, in one patient, complete "ring sideroblasts" (Bowman, 1961). From 30 to $100 \%$ of the erythroblasts contained granules, and in each case the percentage of cells containing iron granules was greater than the corresponding percentage saturation of the serum iron-binding capacity; in normal subjects the percentage saturation of the iron-binding capacity is approximately equal to the percentage of erythroblasts containing iron granules (Bainton and Finch, 1964).

The changes of infection were restricted to patients not receiving chemotherapy or those treated for less than six months (Table V). Changes of iron deficiency occurred with approximately equal frequency among treated and untreated patients. In contrast, excess iron granulation was seen only in the marrows of patients receiving chemotherapy, and was particularly common in the preparations from patients treated for longer than six months. Thus of 14 patients treated for less than six months only three showed excess iron, whereas seven of the 12 treated for 6 to 12 months and nine of the 16 treated for longer than 12 months showed excess iron.

The results of serum iron and iron-binding capacity determinations were generally but not invariably consistent with the bone-morrow iron findings (Figs. 3 and 4). Fifteen of the 19 patients with iron-deficient marrows had serum iron levels less than $65 \mu \mathrm{g} . / 100 \mathrm{ml}$. ; the saturation of the iron-binding capacity in these 19 patients ranged from 5 to $26 \%$. In the 10 patients showing changes of chronic inflammatory disease the serum iron levels were generally reduced, and ranged from 20 to $106 \mu \mathrm{g} . / 100 \mathrm{ml}$. ; the saturation of the iron-binding capacity ranged from 8 to $40 \%$. In the 19 patients with an excess of siderotic granules in the erythroblasts the serum iron levels tended to be high, ranging from 52 to $211 \mu \mathrm{g} . / 100 \mathrm{ml}$. ; the saturation of the iron-binding capacity ranged from 12 to $82 \%$. Five patients, including the one with ring sideroblasts, had abnormally high serum iron levels (ranging from 176 to 211 $\mu$ g. $/ 100 \mathrm{ml}$.).

TABLE V.-Comparison of the Bone-marrow Iron Findings with the Treatment Received by the Patients. The Bone-marrow Iron Appearances are Divided into Four Groups: (1) Normal, (2) Changes of Infection, (3) Iron Deficiency, and (4) Iron Excess

\begin{tabular}{|c|c|c|c|c|c|c|c|}
\hline Patients & & No. & $\begin{array}{l}\text { No. Suitable } \\
\text { for Assessment } \\
\text { of Iron Status }\end{array}$ & $\begin{array}{l}\text { Normal ; \% of } \\
\text { those Examined } \\
\text { (No.) }\end{array}$ & $\begin{array}{c}\text { Changes of Infection; } \\
\% \text { of those Examined } \\
\text { (No.) }\end{array}$ & $\begin{array}{c}\text { Iron Deficiency ; } \\
\% \text { of those Examined } \\
\text { (No.) }\end{array}$ & $\begin{array}{l}\text { Excessive Iron in } \\
\text { Erythroblasts; \% \% of } \\
\text { those Examined (No.) }\end{array}$ \\
\hline $\begin{array}{l}\text { Untreated or not on therapy } \\
\text { Receiving isoniazid }<6 / 12 \\
\text { Receiving isoniazid } 6 / 12-12 / 12 \\
\text { Isoniazid }>12 / 12 \quad . . \quad . . \\
\end{array}$ & $\begin{array}{l}\because \\
\because \\
.\end{array}$ & $\begin{array}{l}22 \\
16 \\
13 \\
17 \\
\end{array}$ & $\begin{array}{l}21 \\
14 \\
12 \\
16 \\
\end{array}$ & $\begin{array}{l}29(6) \\
36(5) \\
17(2) \\
12(2)\end{array}$ & $\begin{aligned} 33(7) \\
21(3) \\
0(0) \\
0(0)\end{aligned}$ & $\begin{array}{l}38(8) \\
21(3) \\
25(3) \\
31(5) \\
\end{array}$ & $\begin{array}{r}0(0) \\
21(3) \\
58(7) \\
57(9)\end{array}$ \\
\hline Total & .. & 68 & 63 & $24(15)$ & $16(10)$ & $30(19)$ & $30(19)$ \\
\hline
\end{tabular}


The patient with ring sideroblastic change was a 40 -year-old man. His haemoglobin concentration (14.4 g./100 ml.), M.C.H.C. (33\%), and M.C.V. ( 89 cubic microns) were normal. The peripheral blood film contained occasional hypochromic cells, and the bone-marrow fragments showed an excess of free iron. Coarse siderotic granules were present in $95 \%$ of the erythroblasts, forming occasional complete perinuclear rings. The serum iron level was $185 \mu \mathrm{g} . / 100 \mathrm{ml}$., and the total ironbinding capacity $278 \mu \mathrm{g} . / 100 \mathrm{ml}$., with $67 \%$ saturation. In addition there was mild megaloblastic change, the serum folate level being $2.8 \mathrm{~m} \mu \mathrm{g} . / \mathrm{ml}$., serum $\mathrm{B}_{12}$ level $310 \mu \mu \mathrm{g} . / \mathrm{ml}$, , and Figlu test positive ( $25 \mathrm{mg}$. in eight hours). He had received P.A.S. $14 \mathrm{~g}$. and isoniazid $350 \mathrm{mg}$. daily for 13 months with, initially, streptomycin $1 \mathrm{~g}$. intramuscularly daily to a total of $89 \mathrm{~g}$.

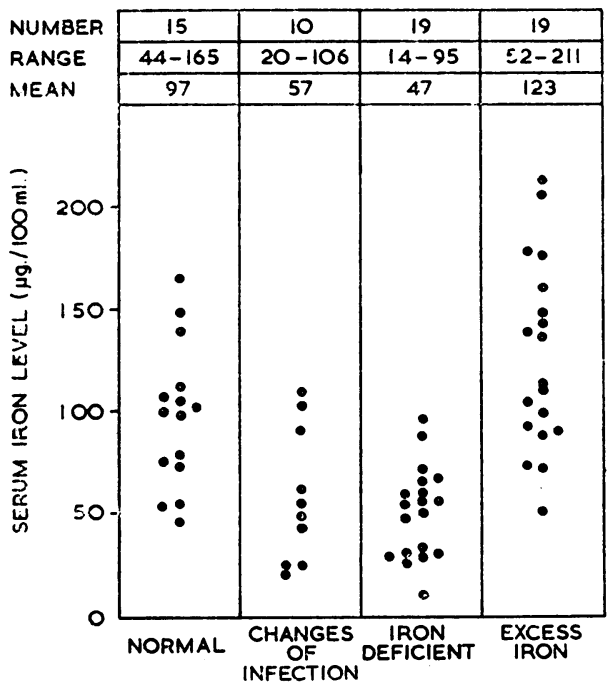

Fig. 3.-Range, mean, and distribution of the serum iron levels of the 63 tuberculous patients in whom the marrow specimens were adequate for assessment of iron distribution.

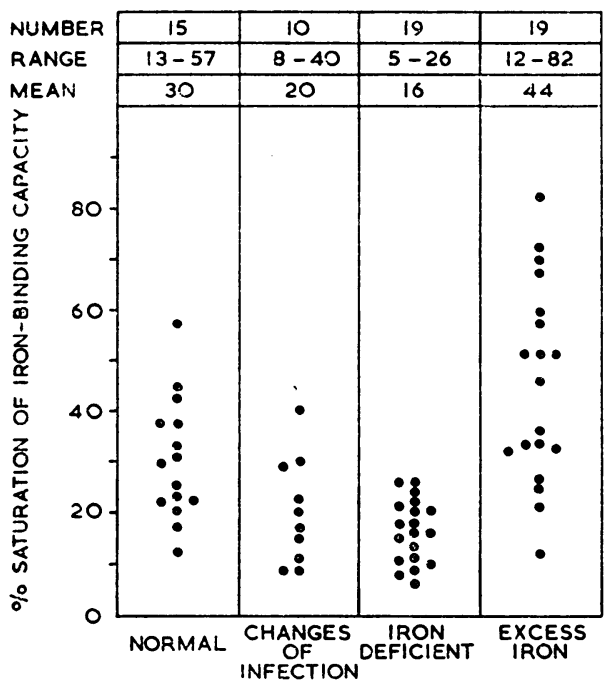

FIG. 4.-Range, mean, and distribution of the saturation of the iron-binding capacity in the 63 tuberculous patients whose serum iron levels are given in Fig. 3.

\section{Discussion}

Descriptions of the association of tuberculous and megaloblastic anaemia are mainly confined to patients with abdominal tuberculosis and associated intestinal strictures, blind loops, or fistulae (Hawksley and Meulengracht, 1936; Mollin and Ross, 1952 ; Thompson and Ungley, 1955 ; Richmond and
Davidson, 1958 ; Doig and Girdwood, 1960 ; Booth et al., 1964). Where adequate investigation was undertaken the megaloblastic anaemia in these cases was shown to be due to $\mathrm{B}_{12}$ deficiency.

In a review of the haematological complications of large numbers of cases of pulmonary tuberculosis by Oswald (1963) megaloblastic anaemia and megaloblastic change in the bonemarrows are not mentioned. None the less, in a few patients with tuberculosis folate deficiency has been noted. Chanarin (1963) mentions a case of osseous tuberculosis in which a strongly positive Figlu test became negative on folic-acid therapy ; Perkins et al. (1964) describe briefly a case of polycythaemia vera and tuberculosis in which megaloblastic anaemia responded to folic acid; and Hansen (1964) refers to three patients with pulmonary tuberculosis and low serum folate levels.

In the present study haematological and biochemical evidence of folate deficiency was found in the majority of the tuberculous patients. There was a high incidence of hypersegmented polymorphs in the peripheral blood films, despite the reported "shift to the left" in the polymorphs in tuberculosis (Undritz, 1952), and megaloblastic marrow changes were common. Subnormal serum folate levels occurred in $88 \%$ of the patients, and the levels were below those of a control series in $35 \%$. These low serum folate levels were not due to a direct effect of the drugs on the growth of $L$. casei, since a single dose of isoniazid and P.A.S. given to three normal subjects did not affect their measured serum folate levels, nor did the drugs affect the growth of $L$. casei when added, in pharmacological amounts, to the assay. Furthermore, Figlu tests and red-cell folate assays, which are abnormal only in relatively severe folate deficiency (Herbert, 1962 ; Mollin and Hoffbrand, 1965), were also positive in $47 \%$ and $33 \%$ respectively of patients tested.

The cause of folate deficiency in tuberculous patients is not obvious. There was no significant correlation between the incidence of the deficiency, assessed biochemically or haematologically, and the clinical and radiological classification of the disease. The deficiency was equally common among treated and untreated patients, and was not related to the length or type of chemotherapy. Brief dietary histories from both in-patients and outpatients produced no evidence of severe malnutrition. Malabsorption of folate was not excluded, though faecal fat excretion was normal in three patients with severe deficiency.

It is possible that increased utilization of folate occurs in tuberculosis owing to chronic inflammation, and that this increased demand cannot be met by an ordinary diet. Alternatively, folate deficiency might predispose to tuberculosis, and this could be a factor responsible for the known high incidence of tuberculosis in malnourished subjects (Rich, 1951) and also in patients after partial gastrectomy, with idiopathic steatorrhoea, and in alcoholics, in all of whom folate deficiency is common. Alternatively, the deficiency could be one indication of a general malnutrition, which increases susceptibility to tuberculous infection.

An excessive number and abnormal size and distribution of siderotic granules in the erythroblasts was found in the marrows of $30 \%$ of the patients. Unlike folate deficiency, this abnormality was confined to patients receiving chemotherapy, and it was particularly common in those who had received isoniazid and P.A.S. for longer than six months, occurring in 16 of these 28 patients. None of the patients had sideroblastic anaemia, though one had numerous ring sideroblasts in the marrow and others had many incomplete ring forms. Some of these patients also had abnormally high serum iron levels and increased saturation of the iron-binding capacities, but in each case the excess of iron granulation in the erythroblasts was proportionately greater than the increase in percentage saturation of the iron-binding capacity. These changes in marrowiron distribution are probably caused by isoniazid therapy, 
being similar to the abnormalities produced by isoniazid in the marrows of experimental animals and in human subjects receiving isoniazid therapy. The exact cause of the change is unknown, but it has been attributed to disturbance of pyridoxine metabolism. The incidence of the abnormality in the present series might have been higher had iron deficiency, which was common in the group as a whole, been corrected before the bone-marrow examinations were made.

\section{Summary}

Two groups of tuberculous patients, 50 treated and 18 untreated, were investigated for abnormalities of folate and iron metabolism. In $30 \%$ of the 68 patients the marrows showed obvious megaloblastic changes. Hypersegmented polymorphs were seen in about one-third of the peripheral blood films, and serum folate levels below the lower limit of a control series were found in $35 \%$ of the patients. Figlu tests were positive in $47 \%$, and red-cell folate levels were subnormal in $33 \%$ of the small unselected proportion of the patients tested. Folate deficiency was equally common among the treated and untreated patients, and its incidence bore no relation to the clinical extent of the disease or to the length or type of chemotherapy.

Excess stainable iron was present in the erythroblasts of 19 $(30 \%)$ of the 63 patients whose marrows were suitable for assessment. The iron granules were coarser than normal, were increased in number, and were often perinuclear in distribution. One patient showed obvious ring sideroblastic change. Increase in marrow iron was confined to patients receiving chemotherapy, and was particularly common in patients treated with isoniazid and P.A.S. for longer than six months, occurring in $16\left(57^{\prime \prime}{ }^{\prime}\right)$ of these 28 patients. Some of these patients also had raised serum iron levels and increased saturation of the iron-binding capacities.

We wish to thank Dr. E. Rhys-Jones and Dr. V. U. Lutwyche, chest physicians to the Harlow Group of Hospitals, for permission to study patients under their care. We are also grateful to Dr. Rhys-Jones for the clinical and $x$-ray classifications of the patients; to Dr. Barbara H. MacGibbon for helpful discussions ; and to Mr. J. Morgan, Miss B. Newcombe, Miss B. Peart, and Mrs. M. Potter for technical assistance.

\section{REFERENCES}

Anderson, B. B. (1964). F. clin. Path., 17, 14.

Bainton, D. F., and Finch, C. A. (1964). Amer. F. Med., 37, 62 Booth, C. C., McIntyre, I., and Mollin, D. L. (1964). Quart. F. Med., 33, 401 .

Bowman, W. D. (1961). Blood, 18, 662.

Caraway, W. T. (1963). Clin. Chem., 9, 188.

Chanarin, I. (1963). Brit. F. Haemat., 9, 141.

- and Bennett, M. C. (1962). Brit. med. 尹., 1, 27.

Dacie, J. V., and Lewis, S. M. (1963). Practical Haematology, 3rd ed. Churchill, London.

Doig, A., and Girdwood, R. H. (1960). Quart. F. Med., 29, 333.

Foster-Carter, A. F., Myers, M., Goddard, D. L. H., Young, F. H., and Benjamin, B. (1952). Brompton Hosp. Rep., 21, 1.

Hansen, H. A. (1964). On the Diagnosis of Folic Acid Deficiency. Almqvist and Wiksell, Stockholm.

Harriss, E. B., MacGibbon, B. H., and Mollin, D. L. (1965). Brit. F. Haemat., 11, 99 .

Hawksley, J. C., and Meulengracht, E. (1936). Lancet, 2, 124.

Herbert, V. (1959). The Megaloblastic Anaemias. Grune and Stratton, New York. (1962). Trans. Amer. Ass. Phycns, 75, 307.

Hoffbrand, A. V., Newcombe, B. F. A., and Mollin, D. L. (1966). J. clin. Path., 19, 17.

Kohn, R., Heilmeyer, L., and Clotten, R. (1962). Dtsch. med. Wschr., 87,1765 .

McCurdy, P. R. (1963). Clin. Res. Proc., 11, 59.

MacGibbon, B. H., and Mollin, D. L. (1965). Brit. F. Haemat., 11, 59.

Mollin, D. L., and Hoffbrand, A. V. (1965). In Vitamin Ba and Folic Acid, Series Haemat. 3, p. 1. Munksgaard, Copenhagen. and Ross, G. I. M. (1952). F. clin. Path., 5, 129.

Oswald, N. C. (1963). Brit. med. 尹., $2,1489$.

Perkins, J., Israëls, M. C. G., and Wilkinson, J. F. (1964). Quart. F. Med., 33, 499 .

Redleaf, P. D. (1962). Dis. Chest, 42, 222.

Rich, A. R. (1951). In The Pathogenesis of Tuberculosis, 2nd ed., p. 618. Blackwell, Oxford.

Richmond, J., and Davidson, S. (1958). Quart. F. Med., 27, 517.

Thompson, R. B., and Ungley, C. C. (1955). Blood, 10, 771 .

Undritz, E. (1952). Sandoz Atlas of Haematology, p. 57. Sandoz, Basle. Verwilghen, R. L, Lahaye, D. van Orshoven, A., and Reybrouck, G. (1963). 9th Congr europ. Soc. Haemat., Lisbon, Abstracts, 32. (1963). Yin Congr. elleps, L., Haend Cosemans, J. (1965), Brit. Haemat., 11, 92 .

Waters, A. H., and Mollin, D. L. (1961), 7. clin. Path., 14, 335.

\title{
Folic-acid Deficiency in Elderly Patients Admitted to Hospital
}

\author{
A. D. F. HURDLE,* M.R.C.P.ED., M.C.PATH. ; T. C. PICTON WILLIAMS, † M.D., M.R.C.P.
}

During routine haematological investigations at the South Western Hospital in 1964 many elderly people had low levels of folate in their serum. In order to establish the incidence of a low serum folate and to attempt to determine its cause we decided to investigate patients over 70 years old admitted to hospital.

A similar investigation into the folic acid status of men and women admitted to an old people's home in Bristol has recently been published (Read et al., 1965). We were able to explore the problem more extensively in a hospital population and to confirm that folic-acid deficiency is common in old age and that dietary deficiency is almost certainly the principal cause.

It was decided to use a faecal fat analysis and a folic-acidabsorption test to diagnose intestinal malabsorption. The D-

\footnotetext{
- Lecturer in Haematology, St. Thomas's Hospital Medical School, London.

† Consultant Physician, Geriatric Unit, South Western Hospital, London; Lecturer in Geriatrics, St. Thomas's Hospital Medical School, London.
}

xylose-excretion test was not used, as it is known to give low values in old people (Finlay and Wightman, 1958 ; Fowler and Cooke, 1960). Cases of folic-acid deficiency due to malignant disease, chronic infection, haemolytic anaemia, etc., or from taking anticonvulsant drugs were excluded by the clinical history and examination and routine blood tests. No patients had alcoholic cirrhosis. The hospital dietitian was asked to make an estimate of the folic acid consumed during the months preceding admission by means of a dietary history and published tables of food values (McCance and Widdowson, 1960).

\section{Material and Methods}

From April 1964 data were collected on 72 patients aged over 70. These people were an unselected group of consecutive admissions to the geriatric unit of the South-western Hospital. There were 46 females and 26 males, the clinical diagnoses on admission being arranged in groups in order of frequency 